\title{
THE EMPLOYEES' PERCEPTIONS OF LEARNING ENGLISH IN A BUSINESS CONTEXT
}

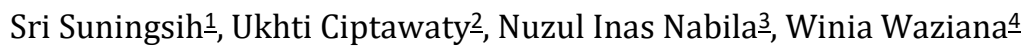 \\ Faculty of Economics and Bussines, University of Lampung $\underline{123}$, STMIK Pringsewu 4 , Indonesia \\ sri.suningsih@feb.unila.ac.id, ukhti.ciptawaty@feb.unnila.ac.id, nuzulinasnabilaa@gmail.com, \\ winiawaziana@gmail.com
}

\begin{abstract}
This study aims to investigate how the English is used in the business workplace.. The researcher used a quantitative and descriptive qualitative method. The data used in this study are from open-ended questionnaire to the employees working in economics and business. The results showed that of the 17 worker participants, 11 participants (36.67\%) thought that reading was most useful in the workplace, such as analyzing or auditing financial reports, preparing documents and calculating bills, operating software and understanding documents of export and import goods, processing data on a computer, using applications related to data calculation input, studying information about international bank rules, reading journals, opening current and personal savings accounts, reading financial reports, and other activities. Meanwhile, 9 participants (30\%) agreed that speaking skills are often used in the workplace. The speaking activity is serving customers from various countries, being interviewed in the recruitment process. Listening skills were obtained by 5 participants $(16.67 \%)$, which mean that they are rarely applied by the participants. In applying Listening skills, participants use them when understanding conversations from universities abroad. There were 5 participants (16.67\%) who chose to write the most in their works, such as answering emails, writing essays, opening checking accounts, and saving savings, making financial reports. The result also reflects the workers' learning experiences while learning English in the colleges show the several topic discussion they learnt such as Introduction, and general English, the topics about finance/ accounting material and financial reports, venture capital, stocks and bonds, which are usually useful when meetings with foreign principals or other employees and their supervisor, Writing, reading, discussion, communication, Vocabularies, Determination of the stock price index, Management, recruitment, accounting, financial statement, Learnt accounting using English books and also learnt about English conversation its very useful for my work, Vocabularies about accounts related to financial statements. In addition, another participant responded that English that is learned on campus and at work is very different. Not all English skills are applied in the respondent's workplace, only reading is used most often. In term of English needs in the workplace, the professionals need Speaking skills and English language terms according to business context.
\end{abstract}

Keywords: ESP Materials; English for Business, Workers' Perceptions.

Copyright (C) 2021, International Journal of Economics, Business and Entrepreneurship | IJEBE | FEB-UNILA

\section{INTRODUCTION}

Nowadays the needs of English are increasing and vary according to their needs and functions; moreover, the world has entered internalization 4.0 where all data can be accessed online and in English. But not many of us are hindered by the lack of English skills when accessing the information presented. Although several machine translators are 
available, there are several English terms in specific destinations that are often different from general English. Besides, teaching English is less correlated with the world of work. Therefore teaching business English needs to be taught as a general course that must be followed by students as capital to compete in the world of work. The English teaching model applied at the University is carried out specifically through the English for Specific Purposes learning model which is applied in accordance with the realm of the area of each student's needs such as English for Business, English for medical purpose, English for tourism, English for Engineers, English for technicians, etc. So, teaching English for Specific Purposes has a different approach to General English where ESP content applies to students' needs. (Ramani, 2016) In their research (Ramani, 2016), they indicated that English language programs around the world have become increasingly aware of the need to review the curriculum due to the demographic and situational changes taking place. As the student population, societal views, and institutional factors keep changing, English programs need to adapt to the curriculum. Therefore, the review process of the English program needs to be implemented regularly to make the changes needed to facilitate the desired results.

According to Gravatt, Richards, and Lewis (1997) in Ramani, (2016), The following procedural options can be carried out to design a needs analysis that can provide a holistic view of the needs of students and represent the interests of the different stakeholders involved. It is important to make decisions on the realistic procedures involved in the collection, arrangement, review and reporting of the information collected. It is necessary to ensure that the analysis of needs does not generate an abundance of knowledge. There need to be clear reasons to gather some information to ensure that only the information that will be used is collected. These procedures include: literature survey, review of various survey questionnaires, contact with others who have done similar things, survey interviews with lecturers to decide goals, identification of participating departments, presentation of project proposals to participate in departments and identification in each department of contact persons in Indonesia, Development of a questionnaire for pilot students and staff, Review of questionnaires by colleagues, Checking of questionnaires, Selection of staff and student subjects, Development of a data collection schedule, Administration of the questionnaire, Continuing interviews with selected participants, Tabulation of responses, Study of responses, Writing reports and recommendations

(Arianti, 2017) suggested that students in non-English study programs need English language teaching to prepare themselves for lectures (EAP) and to prepare themselves for work competition (EOP). In preparation for EOP, students feel they have the ability and are more or less able to master the material related to job interviews as a provision in finding work. That is because students consider the interview as a crucial thing when entering work confusion. Mastery of English in terms of job interviews makes the value/points more so that there is a high probability of being received at the relevant institution. Meanwhile, in facing work competition, students feel the need to prepare themselves fluently in English, especially in terms of their ability to communicate orally or speaking. Students emphasize the importance of developing speaking skills as one of the key objectives of learning English in semester 2 in preparing the requirements as provisions for entry into the workforce, which is then accompanied by increasing other skills such as writing, reading and listening 
skills. The purpose of learning English for economics students in semester 2 is to improve the requirements as provisions for entry into the workforce.

Dyah Ayu (2015) analyzed the needs of students (wants) for learning English, the result was that $50 \%$ of Agroindustrial Management students placed improved oral communication or speaking skills and 30\% writing as the top priority in learning English for preparation enter the workforce. While all this time learning English in the Agroindustry Management class focuses more on reading skills (Reading), this is in accordance with the questionnaire data which shows that $6.7 \%$ of Agroindustry Management students place reading skills as a goal of learning English.

In her research findings (Mutmainna, 2013), she showed that learning criteria consist of language skills and preferences for learning. In language abilities, all language abilities are used in the class at a "always" level. In learning preferences, paired learning is favored over others in terms of learning English with others while learning preferences are often preferred by students in terms of learning using teaching methods, learning by listening and speaking, and role-playing. The use of English at work consists of language needs. Face to face with hotel guests, especially foreigners, English is often used. The current syllabus was revised by researchers by introducing some topics required by students and often used in the workplace in the language of service, greeting, welcoming hotel guests, providing assistance and advice, as well as describing hotel facilities mostly used by employees at the hotel.

(Hasriadi, et al, 2019) revealed in his research that students of the accounting program require special English learning material that has a strong connection with their study program. Although it is important to combine English language skills with accounting knowledge goals, especially reading to understand some reports and writes presentation papers. Ulum (2015) It was found that more supportive material for learning to talk must be required, and more authentic and interesting exercises should be conducted.

There are some guidelines to the concept learning course. Kalamees-ruubel (2019) stated that Seven steps are included in the curriculum process: diagnosing criteria, formulating expectations, selecting material, arranging content, selecting learning experiences, organizing learning experiences, and deciding assessments. In the context of the design of a language course, Graves (2000) points out a language course design is a work in progress in its entirety, in its components and in its implementation.

Based on the background, phenomena, and research results above, researchers are interested in conducting further research, because it is needed follow-up research to respond to the recommendations of previous researchers, the need for a wholeness analysis is carried out to produce qualified teaching output. Besides, the lecturers also act as the researchers in this research need a teaching source that is appropriate, effective, and useful in the workplace. This research is the first research that focuses on Indonesian students' and professionals' needs in term of English in the academics and English in the work place, this focusing to the designing ESP materials for Economics and Business Students based on needs analysis has not been done by other researches. Therefore it is expected that the quality output of teaching, or curriculum/learning tools that in practice or theory can 
answer the problems and give the solution to the ESP lecturers in providing applicable materials for Economics Students.

\section{METHODS}

The participants of this research are 17 professionals who work in Economics fields. The instrument used to collect data was the result of questionnaire of professionals, The professionals/ workers/ alumni of accounting who work in accounting fields: open-ended questionnaire that aims to collect data on the English language needs of professional or workers in the work place. The professionals were asked about English skills mostly used in the workplace, example of job activities that often use English, their learning experiences while learning English in their colleges.

This study describes the facts and information obtained in the field, and makes a systematic, actual, and accurate picture of the relationship between the variables studied and the implications of a problem under study.

The research design used are quantitative and qualitative method. The descriptive qualitative used to describe the perceptions of employees on learning English in Business Context.

\section{RESULTS AND DISCUSSION}

The participants' English skill needs are presented in the diagram below;

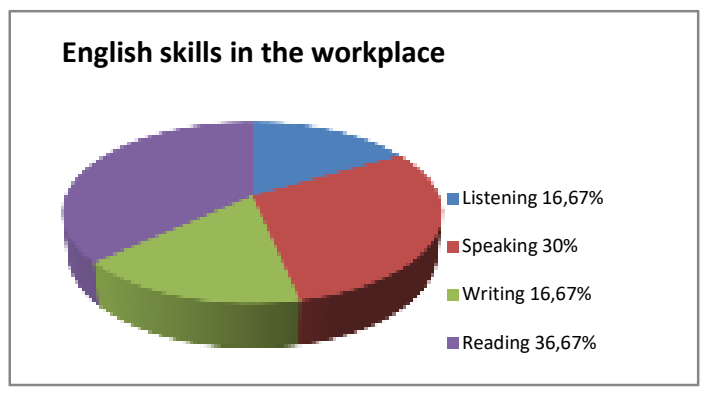

Diagram 1. English Skills in the Workplace

The results showed that of the 17 worker participants, 11 participants (36.67\%) thought that reading was most useful in the workplace, such as analysing or auditing financial reports, preparing documents and calculating bills, operating software and understanding documents of export and import goods, processing data on a computer, using applications related to data calculation input, studying information about international bank rules, reading journals, opening current and personal savings accounts, reading financial reports, and other activities. Meanwhile, 9 participants (30\%) agreed that speaking skills are often used in the workplace. The speaking activity is serving customers from various countries, being interviewed in the recruitment process. Listening skills were obtained by 5 participants (16.67\%), which mean that they are rarely applied by the participants. In applying Listening skills, participants use them when understanding conversations from universities abroad. There were 5 participants $(16.67 \%)$ who chose to 
write the most in their works, such as answering emails, writing essays, opening checking accounts, and saving savings, making financial reports.

From the result of interview, English used in the workplace from different job positions such as a Treasurer, Budget Manager Analysis, Tax Officer, Bank teller, Head of administrative affairs of the budget implementation division, finance administrator, Accounting Staff, Tax Consultant, Head of the Ministry of Transportation's Finance and Human Resources sub-division, Accountant, The staff in credit of Segment Small Medium Enterprise, Bank Manager, and Banker. The jobs activities that they need English such as managing the budget and making financial reports using English. English may also be used by receptionists who receive guests and also help desk officers who receive and answer all questions asked by the questioner, Meeting with principals from abroad, in making financial report. In addition, listening and speaking to serve the client, reading journal, and writing write essay, processing a tax data into the taxation system, serving guest from other countries, routine bookkeeping activities, operating hardware tools, programming, financial report, and responding email, interviewing process, and collaborating with foreigner, inputting data calculation, operating the software and understanding some documents such as export and import goods documents, understanding and filing tax documents (tax documents on export and import goods), preparing documents to calculate, bill, deposit and report taxes, getting project to other countries, sending emails or chatting to collages abroad to discuss jobs such as monthly closing, financial reports, or any other inquiries related to work, NetSuite for financial reporting, ang having conference calls with colleagues abroad, analysing, and auditing financial report, meeting with clients, learning information about rule of international banking, etc, and opening of current accounts or personal savings.

Based on the result of interview, the professionals' learning experiences while learning English in the colleges show the several topic discussion they learnt such as Introduction, and general English, the topics about finance or accounting material and financial reports, venture capital, stocks and bonds, which are usually useful when meetings with foreign principals or other employees and the supervisor, writing, reading, discussion, communication, vocabularies, determination of the stock price index, management, recruitment, accounting, financial statement. In addition, some participants responded that English learnt on their study and work are mostly different. Not all English skills are applied in the respondent's workplace, only reading is mostly used in the office. In term of English needs in the workplace, the professionals also need Speaking skills and English Business to their works.

On accounting materials and financial statements, the respondent use as a reference for making and reading financial statement reports in English, since there are often differences in the language system in making financial reports between the Indonesian versions of financial statements with English. That way the respondent can have a good ability to make financial reports and bookkeeping in the Indonesian version and the English version when ordered by superiors. Furthermore, there is a topic of venture capital, as 
employees in finance or accounting; they are required to provide financial analysis results to be used as material for future company decisions. Financial analysis, such as providing details of business performance in the form of financial reports and other records, which shows estimated earnings for a month or more the company operates. With this, the management can make projections for future income and also determine investors to provide investment after seeing the company's business performance through financial statements. Given this, the ability of respondents in making financial reports in English is very necessary considering that investors are also many from abroad and also have to make financial analysis which contents are useful for planning and making business strategies in the future.

\section{CONCLUSION}

The research is carried out to produce qualified teaching output and provide teaching source that is appropriate, effective, and useful in the workplace. This research focuses on the perception of employees on learning English in Business context or English for Occupational Purposes. Therefore, it is expected that the quality output of teaching, or learning tools that in practice or theory can answer the problems and give the solution to the ESP lecturers in providing applicable materials for Economics Students.

This study might not be enough to generalize. Besides, the researchers obtained the data from the participants that might be in subjective point of view. Therefore, it is suggested to future study to conduct or continue the needs analysis for accounting students through different concept. Although having some limitation, this study is significant for in helping the lecturers in the decision of determining the appropriate ESP materials for Economics students. Based on the analysis of the needs of business English in the job objectives, it was found that there was a similarity in the relationship that in academic goals students needed reading skills which were useful for increasing vocabulary, insight, and perfecting other language skills. Thus, it is necessary to consider the structure and variety of reading learning materials that are effective, attractive, to meet student needs.

\section{REFERENCE}

Arianti, A. (2017). ANALISIS KEBUTUHAN BAHASA INGGRIS PADA MAHASISWA NON BAHASA INGGRIS. September, 50-52.

Goulart, L., Paula, A., Vial, S., \& Sarmento, S. (n.d.). Developing English for Academic Purposes ( $E A P$ ) teaching materials : a needs analysis of novice teachers.

Graves 2000. (n.d.).

Hutchinson and Waters. (1987).English for specific purposes, New York: Cambridge University.

Hyland, K. (2006). English for Academic Purposes. London: Routledge.

Ian Mackenzie (2010). English for Business Studies. A course for Business Studies and Economics Students. New York: Cambridge University.

Kalamees-ruubel, K. (2019). The Taba-Tyler Rationales. December. 
Lynne Flowerdew (2013). The Handbook of English for Specific Purposes, First Edition. Edited by Brian Paltridge and Sue Starfield.@ 2013 John Wiley \& Sons, Inc. Published 2013 by John Wiley \& Sons, Inc.

Mutmainna, I. (2013). Revision english course syllabus based on students' language need and learning need of hotel accommodation department at smkn 8 makassar inna mutmainna.

No Title. (n.d.). Mid.

Pd, S. (2016). English for Specific Purposes for Accounting Students. 3(2), 144-148.

Ramani, T. P. (2016). Importance of needs analysis in ELT Curriculum International Journal of Advanced Multidisciplinary Research (IJAMR) Research Article Importance of needs analysis in ELT Curriculum. April.

Richard Syllabus Design. (n.d.).

Richards, C., Platt, J. \& Platt, H. (1992) Dictionary of Language Teaching and Applied Linguistics. Malaysia: Longman.

Salija, K., \& Makassar, U. N. (n.d.). Needs Analysis of English Materials for Accounting Study Program.

Ulum, Ö. G. (2015). European Journal of English Language Teaching A NEEDS ANALYSIS STUDY FOR PREPARATORY. 14-29. 